\title{
Developing a conceptual model for the relationship between rituals and the city based on the Theory of Sense of Place: the case of the historical texture of Gorgan, Iran
}

\author{
Desenvolvendo um modelo conceitual para relação entre \\ rituais e cidades baseado na teoria do sentido de lugar: o \\ caso de Gorgan, Irã
}

Masoumeh Livani[a] [D), Hamidreza Saremi[a] [D. Mojtaba Rafieian[a] [D

[a] Tarbiat Modares University, Faculty of Arts and Architecture, Tehran, Iran

How to cite: Livani, M., Saremi, H., \& Rafieian, M. (2021). Developing a conceptual model for the relationship between rituals and the city based on the theory of sense of place: the case of the historical texture of Gorgan, Iran. urbe. Revista Brasileira de Gestão Urbana, v.13, e20200139. https://doi.org/10.1590/2175-3369.013.e20200139

\section{Abstract}

The aim of this study is to investigate how the city is influenced by the ritual of Muharram. The main research question is: what is the relationship between the city and the ritual of Muharram? To answer this question, we examined different intangible layers of this ritual heritage. This study is based on the three components of the sense of place. The research method is qualitative and a context-oriented approach is adopted. The context of the study is the historical texture of the city of Gorgan, Iran. The data were collected through library research and immediate observation. Next, content analysis and data coding were used to obtain a set of thematic categories. The results suggest that, as a kind of ritual-social behavior, the ritual of Muharram has had remarkable, enduring effects on the city over centuries. The non-urban-development dimension has thus allowed for the formation of sense of place in the relationship between people and the urban environment through a different process.

Keywords: Muharram ritual. Senseof place. Thehistorical texture of Gorgan. Tangibleheritage. Intangibleheritage.

ML is Ph.D. student of Urban and Regional Planning Department, e-mail: masoomeh.livani@modares.ac.ir HS is Associate Professor and Faculty Member, PhD in Urban Planning, e-mail: saremi@modares.ac.ir (corresponding author). MR is Associate Professor and Faculty Member, PhD in Urban Planning, e mail: rafiei_m@modares.ac.ir 


\section{Resumo}

O objetivo deste trabalho é investigar como a cidade é influenciada pelo ritual de Muharram. A principal questão da pesquisa é: Qual a relação entre a cidade e ritual de Muharram? Examinamos diferentes camadas de heranças intangíveis deste ritual a fim de responder tal questão. Esse estudo é baseado nos três componentes do sentido de lugar. $O$ método de pesquisa é qualitativo e uma abordagem orientada pelo contexto foi adotada. $O$ contexto deste estudo é o resgate histórico da cidade de Gorgan, Irã. Os dados foram coletados através de pesquisa bibliográfica e observação direta. Posteriormente, análises de conteúdo e codificação de dados foram usadas para obter um conjunto de categorias temáticas. Os resultados sugerem que, como um tipo de comportamento ritual-social, o ritual de Muharram teve efeitos contundentes no desenvolvimento da cidade ao longo dos séculos. A dimensão do desenvolvimento não urbano tem permitido a formação do sentido de lugar na relação entre pessoas e o ambiente urbano através de diferentes processos.

Palavras-chave: Ritual Muharram. Sentido de lugar. Contexto histórico de Gorgan. Herançatangível. Herançaintangível.

\section{Introduction ${ }^{1}$}

The development of cities in societies concurrent with the Islamic rule was gradually transformed through influences from Islamic beliefs (Khaledian, 2014).From the early Islamic period onwards, the urban spaces which were a physical context for social activities came to be affected by the dominant Islamic ideology. Characteristic of these spaces was their ritual-oriented nature, i.e. they hosted numerous collective rituals. These characteristics cannot be discovered at the first encounter with these spaces. Contemporary cultureoriented approaches to urban regeneration have focused on the intangible and spiritual heritage of cities (Lotfi, 2008). In culture-oriented urban regeneration, culture is conceived as the most fundamental element of identity that has acted throughout the history as the basis for the spatial configuration of cities. Culture incorporates a wide range of different social values which are all intangible (Howkes, 2001). Rituals are religiously-oriented, collective customs. One type of ritual is urban ritual. As one of the most influential rituals of Shi'ite Muslims, the ritual of Muharram began in the first and second centuries A.H. and became remarkably popular in the fourth century A.H. From its very beginnings, this mourning ritual turned into the first type of Islamic drama (Avery et al., 1991). Some researchers including Peter Chelkowski even regard it as the only dramatic genre in the Islamic world(Chelkowski, 1979).Many studies have so far been conducted on rituals in general (on a global scale) and Muharram ritual in particular (in the Muslim world). These studies can be classified into two groups:

1. Studies of cities and religions

2. Studies of cities and rituals (addressed in the present paper)

Researchers have investigated these relationships through different lenses. Ahari (2015) and Masoudinejad(2018) have particularly addressed the ritual of Muharram. In an attempt to develop a comprehensive approach to identifying a secondary structure for this ritual, Ahari recognizes three dimensions, i.e. associational, topological, and positional, which are separate from the urban structure. However, he does not examine further details as well as how the underlying layers of this structure could be explained (Ahari, 2015). Masoudinejad recognizes this ritual as a kind of urban ritual. He views the ritual of Muharram as a collective-ritual behavior that has resulted in ritual spaces (Masoudinejad, 2018).

He argues for the dynamic nature of the Muharram ritual as well as its transformational effect on the city. In this regard, he focuses on the spatial structure of collective Muharram ceremonies and looks for the social and spatial logic of these ceremonies.

${ }^{1}$ This article is taken from my doctoral dissertation entitled "Explaining the ritual foundations of urban spaces in the city of the Islamic era". 
The point of departure of the present study is the gap that exists in the previous studies concerning the underlying layers of interaction between this ritual and the city. Iranian cities have been affected by Muharram on different scales. This has resulted in visible and invisible effects on the relationship between human and the city. However, the details of this influence on people and cities have been mostly neglected in the literature.

Thus, the main aim of this study is to investigate the relationship between the spatial structure of the Muharram ritual and the urban space. We selected that part of Gorgan for our study which dates back to Qajar period. This part, which is a large portion of the central and historical core of the city, has been used as the main location for the mourning ceremonies of Muharram. The spatial structure of this location which has had the largest share in holding the Muharram ritual and plays a crucial role in everyday life has characteristics that deserve to be studied through fieldwork. Thus, we have adopted a qualitative method and a context-oriented approach. The data were collected through library research and field observations and then analyzed using content analysis and coding. As culture is a local concept and should be addressed in a bottom-up manner, a context-oriented approach seems to be necessary for obtaining more accurate and reliable results.

\section{Research Method}

The research method in this study is qualitative. The data were collected through library research and immediate observation. In our library research, we used both primary and secondary literature to obtain the required data. For immediate observation, we participated for two consecutive years in all of the ceremonies of Muharram in the historical district of Gorgan, Iran, and recorded the rituals by means of observation, photography, and taking field notes. The samples were selected from among those that were considered as average instances of the phenomenon. Next, content analysis and coding were conducted on the data. Finally, the codes were closely studied and classified into several categories that would be used in the final analysis. For writing this paper, we also used academic papers, books, and doctoral dissertations.

\section{Theoretical Background}

Centrality of place and its building block came into vogue as a result of the social crisis of modern urban development in creating places without identity, history, and relevance (Habibi, 2008). The evolution of this notion began with Lynch's (1979) idea of the mental image of place and how the physical structure could contribute to this image. Characteristic of this approach was the focus on the physical features of space, the variety of activities, and the imaginations produced in people's mind. Theorists such as Canter (1977), Punter (1991) and Relf (1976) proposed models which aimed to clarify the components of place(Rezvani, 2018). In general, the components of all of these models have very much in common and can be classified into three main categories:

1. Physical components

2. Functional components

3. Mental images of space

These can be considered as the main components of the sense of place and the sense of belonging.

As with the physical component, the physical features of the environment can contribute to the sense of place through meaning-making and preparing the context for certain activities. These features are either dynamic elements (such as temperature, sound, etc.) or static ones (such as dimensions, proportions, forms, etc.). Researchers have so far proposed various definitions of these features concerning different spatial scales. This variety is indicative of the importance of the physical dimension in people's understanding of the environment. In fact, theorists believe that the sense of belonging to a place should be created through a 
Developing a conceptual model for the relationship between rituals and the city based on the Theory of Sense of Place

physical context. The most important factor of the sense of place is the users' manipulation of the environment. This refers to putting one's own signature on places where one lives and works, sometimes by shaping the facilities withing the space according to one's own purposes and sometimes by creating one's desired mental image of the space (Habibi, 2008; Falahat, 2006; Lynch, 1979; Bentley, 1985).

The activity component includes the activities performed in the place and is a major factor of the liveliness and identity of the place. The events that occur in the physical context contribute to the sense of place. Examples of this component include social uses, involving people which take place in the space, and social interaction. This indicates that mutual social relationships are among the most important human activities in places and humans enter these relationships according to their needs and desires. The physical dimension of place has a strong effect on the amount of activities performed inside it. In some cases, a certain activity on the part of users may change the environment in a way that represents their desires, values, and personality traits. Thus, the environment is idolized into what the users are longing for.

The meaning component is realized through an individual's, or a group's, understanding of the environment. This involves the internalization of the understanding of a place and the formation of a mental image of that place. The sense of place of place results from a person's inner relationship with the environment, his or her mental conceptions, and the features of the environment (Mirgholami \& Ayshem, 2016). It is in the framework of a cognitive system that an individual develops a sense of belonging to the themes, people, objects, and concepts within a place. In general, the meaning component of space refers to issues such as personal perception of space, memory, association and symbolism. A major factor of place identity is the meaning of place in people's mental images and memories. It depends on the depth of the understanding of place and causes events to occur and memories to form over time (Habibi, 2008).

According to the theory of sense of place in urban development, the above three components can be realized in a physical context so that any urban design framework requires a physical context as a prerequisite for the sense of place and increased sense of place of place depends on the physical quality of space. The growth in the interdisciplinary aspects of urban development in today's world has increased the importance of nonurban-development factors that affect urban development. The effect of these factors on the final quality of urban space has been explored in urban psychology and sociology. In these studies, discussions on the experiences and beliefs of people as well as the culture of society indicate that factors which are hidden in the underlying layers of space can result in multiple, and sometimes quite unique, features in urban spaces. In the same vein, the present study seeks to discover the hidden layers of meaning that contribute to the sense of belonging to place in the urban spaces in question. The authors believe that non-urban-development factors which have their roots in religious beliefs have led to a strong sense of place. Tracing these factors and exploring their relationships to the urban space help us to regenerate the lost sense of belonging in contemporary cities.

Rituals are as old as human civilization and have various manifestations in different peoples due to their origins in the culture. The definitions of the notion of ritual have evolved from early formal conceptions to more sophisticated interpretations of their effects on the underlying structure of human societies. Performance of rituals as a collective experience is among the most durable social activities that strongly influences the psychology of the environment as well as interpersonal and human/environment relationships. Asad (1993) offers a basic and clear-cut definition of ritual and defines it as a set of instructions for religious ceremonies. In this definition, the emphasis is on how the ceremony is performed. In the 19th century, rituals were studied in terms of their relationship with the urban community. Their cultural, social, and psychological aspects were considered as the most important dimensions of their effect on the society. Van Gennep(1960) has made insightful remarks through his unique conception of ritual. He believes that human life is like a journey with different stages. Passing through each step and entering another one entail specific rituals. What is important is how to leave one stage and enter another. Gennep explains this transition as being composed of three steps, 
i.e. pre-threshold, threshold, and post-threshold. These steps refer to separation from the previous stage, transition to the next stage, and integration into the new stage, respectively. The most vital function of rituals is to make individuals capable of moving from a certain state to another. He depicts the importance of rituals in making the collective life to leave a normal state. In contrast to Gennep's unifying view, Gluckman discusses an individual's tendency toward numerous groups by re-examining and criticizing Durkheim's ideas. He notes that the unity of people in a society will be accompanied by certain social conflicts. A member of society belongs not to one group, but to many groups simultaneously. He or she may be friends with somebody in a network but their adversary in another network (Gluckman, 1962)

Masoudinejad (2018) argues as following: "In recent years the role of religious rituals has been increasing as a social practice which can transform the urban society". In his book titled "Rituals of the Passage" (published in Persian), he has discussed the Shi'ite ritual of Muharram in detail. He argues that rituals have not been lost at all in the urban environment. Conversely, they have an integral role in social relationships. His discussion, however, is only restricted to the time of the Muharram rituals. Although the time of these rituals is very limited, it has proved to be very influential in the transformation of social relationships in the urban society (Masoudinejad, 2018).

The ritual of Muharram refers to a set of collective ceremonies held in public in the month of Muharram to mourn over the martyrdom of Imam Hussein, the third imam of the Shi'ites, on the Day of Ashura almost 1400 years ago. Mourning for Imam Hussein is of particular importance in all Shi'ite rituals and has left a great influence on this culture(Tavakoli Bina, 2015). The ritual of Muharram began in the dynasty of Al-e Booyeh in Iran and the first recorded collective mourning ceremony dates back to 963 under the rule of Mo'ezz-odoleh(Chelkowski, 1979).This ritual is a collective, religious activity that has its roots in the society's beliefs. Its original aim was beyond merely developing a mental image and creating memories. Masoudinejad (2018) has examined this religious ritual among the Shi'ites of India. In spite of all the limitations governing the cities in India, the ritual has continued to be performed. Masoudinejad (2018) doesn't emphasize the physical context in which it is held; rather, what matters to him is the holding of the ritual per se. The point that remains ignored is that the survival of this ritual in different cultures has been different. In societies like India where there are many conflicts between the followers of different religions, the activity dimension has been a powerful force to help the ritual survive. In Iran, in which the majority of people are Shi'ites and social solidarity concerning the ritual of Muharram is more prominent than conflicts, other dimensions need to be extracted and explored. Although the main aim of this ritual in Iranian cities is to reinforce religious beliefs and remind people of the martyrdom of Imam Hussein, prolonged performance of this ritual over centuries has resulted in the formation of specialized urban spaces. The activities performed during this ritual influence ordinary urban activities and turn the entire city into a stage for Muharram. Performing the ritual (as a social and religious factor rather than an architectural and urban one) at different levels has had secondary effects on some urban spaces and made them into memorable spaces with specific physical features. Although performance of the Muharram ritual goes back to the second and third centuries A.H., the formation of specific physical-spatial structures dates back to Qajar period. Ahari (2015) has studied a large number of these structures in various Iranian cities and attempted to confirm the existence of a secondary specific structure alongside the ordinary urban structure. Three dimensions can be generally inferred from the previous studies: physical, activity-related, and mental dimensions. In the library research and field observations conducted in the present study, all of the three components guided the investigation of the relationship between the ritual and the city. The field of the present study is the historical texture of Gorgan which is the first nationally registered historical urban district in Iran and bears the oldest evidence of holding the rituals of Muharram in tekyehs among all Iranian cities. 


\section{The Ritual of Muharram in Gorgan}

A body of volunteers were originally responsible for the performance of the Muharram ritual in Gorgan. These volunteers endowed some properties to help establish the foundations for holding this ritual within the first century of its beginnings (1719). These endowments were first rudimentary equipment and then they gradually went further to include land or construction of tekyeh complexes in neighborhood centers (1786). Tekyeh complexes in each neighborhood center has a public main tekyeh (called pir-tekyeh, meaning the great tekyeh) and several tekyehs named after their founders which belong to their family. Until today, part of the expenses of the ritual is provided by the endowed properties. Other expenses are covered by inheritors who are alive and their family. Family endowments has been a major factor contributing to the maintenance of the traditional form of the ritual, the survival of tekyehs, and non-governmental management of the ritual (as opposed to governmental management which always seeks law and order instead of protecting traditions).

According to the oldest existing endowment letter, the mourning ritual of Muharram in Gorgandates back to the late Safavid period (Sotoodeh, 1998, p. 387). The ceremony consisted of walking in groups (called dastehravi) along paths that connected neighborhood centers.

Examination of this endowment letter indicates that performing the ritual has been only for men from the beginning. The presence of women has been confined to sitting at the corners and on the platforms to watch the ceremonies. Currently, females are no longer limited in participating in the ritual and sometimes the women in a mourning group even outnumber the men.

According to Livani (2012), the ritual of Muharram in Qajar Gorgan was performed through a number of stages:

1. First, people gathered in the center of a neighborhood and moved in a specified order toward other neighborhood centers. This moving group which was called a dasteh made a stop at each neighborhood center.

2. During the movement of the group, certain forms of verbal drama were performed. These verbal plays would later turn into different types of ta'ziyeh (a type of Iranian ceremonial drama).

3. Mobile groups of ta'ziyeh gradually developed into stationary ta'zieyh plays which were performed in the open space in neighborhood centers. The spectator took seats around the space and the play was performed in the center.

4. Over time, a fixed physical space was shaped in the neighborhood center for the ritual ceremonies of the month of Muharram. It is maintained that the construction of each tekyeh complex was begun with building the main tekyeh in this space. The main tekyeh was founded publicly and opened to the public. Other tekyehs were founded by families which were usually inhabitants or owners of the houses or other buildings surrounding the main tekyeh. They dedicated part of their land or estate to a tekyeh. The tekyeh was usually used by their family and relatives. Sometimes, meals were served to the public during the rituals.

In general, Shi'ite beliefs and customs were widely spread in Qajar period (Bineshifar, 2015). In this period, religious rituals were spread all over the country. Infact, there was a turning point at different levels of the society(Afshar, 1995). Mourning rituals of Muharram enjoyed a stable and important status and turned into a major part of people's life. This could be partly explained by the king's respect for Shi'ite imams(Hesam Mazaheri, 2008).

The limited historical documents as well as oral reports from the elderly observers indicate that the pattern of the Muharram ritual in Qajar period was similar to what is performed today. This specific pattern consisted of collective circular motion of groups in the center of the tekyeh and moving on certain paths, which are still performed. 
The ritual was so popular in Qajar period that certain physical spaces were created in neighborhood centers for watching the ceremonies. These spaces were rooms surrounding neighborhood centers which were known as tekyeh.

The tekyehs of Gorgan were endowed rooms around neighborhood centers for holding the Muharram ritual which survived through further endowments. These rooms have other uses throughout the year and turn into tekyehs in the month of Muharram.

As Gorgan is a city consisting of many different peoples and some immigrant groups that share a religion, the ritual of Muharram is a common language to create solidarity among the inhabitants of neighborhoods. Planning to perform the ritual is an act of coordination among the neighborhoods. According to the existing documents, the initial core around which Gorgan was formed is Meydan neighborhood. The other main neighborhoods are Sabzeh-mashhad and Nalbandan. Each of these three neighborhoods contained smaller neighborhoods in itself. Every neighborhood had a center and every neighborhood center had a tekyeh complex which was named after the neighborhood. The names have remained unchanged until this day (Zabihi, 1984, p.122-123). This structure dominated the spatial organization of the city for almost two centuries. In Pahlavi period, however, emergence of modernist urban development led to fundamental changes in this organization.

Following these exogenous changes, some tekyehs were destroyed and some suffered physical and spatial damage. However, the importance of this ritual in Gorgan resulted in the restoration of the damaged tekyehs. Some of the destroyed tekyehs were reconstructed in other places. Even under these conditions, the ritual was not stopped and its general pattern has continued until the present day.

Table 1 -The plan of each tekiyeh with the detail of its physical surroundings

(continues)

\begin{tabular}{llll}
\hline $\begin{array}{l}\text { Name of } \\
\text { neighborhood }\end{array}$ & $\begin{array}{l}\text { Physical features } \\
\text { The visual richness of the } \\
\text { tekyeh complex }\end{array}$ & $\begin{array}{l}\text { General view of the tekyeh } \\
\text { complex }\end{array}$ & $\begin{array}{l}\text { Mass and } \\
\text { spaceConnection } \\
\text { with the path } \\
\text { network }\end{array}$ \\
\hline Na'lbandan & $\begin{array}{l}\text { Land use } \\
\text { map during } \\
\text { the year }\end{array}$
\end{tabular}

Table 1 - The plan of each tekiyeh with the detail of its physical surroundings

(conclusion)

\begin{tabular}{llll}
\hline $\begin{array}{l}\text { Name of } \\
\text { neighborhood }\end{array}$ & Physical features & & \\
\cline { 2 - 4 } & $\begin{array}{l}\text { The visual richness of the } \\
\text { tekyeh complex }\end{array}$ & $\begin{array}{l}\text { General view of the tekyeh } \\
\text { complex }\end{array}$ & $\begin{array}{l}\text { Mass and space } \\
\text { Connection with the } \\
\text { path network }\end{array}$ \\
\hline
\end{tabular}




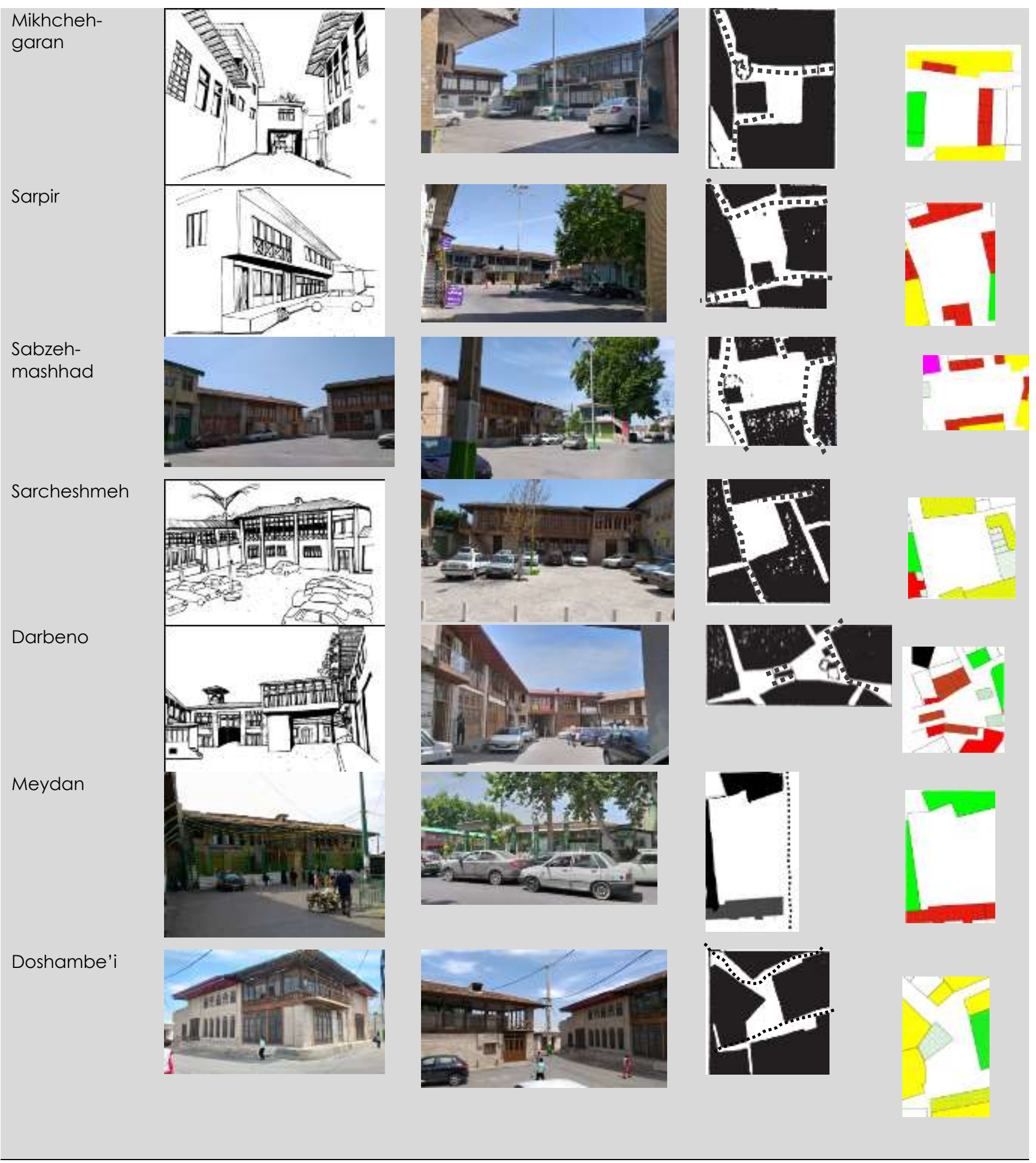

Source: The authors.

The land-uses referred to in the above table (Table 1) are temporarily changed to tekyeh during the Muharram ritual. For this purpose, each room is evacuated and carpeted. Each room belongs to a family or certain profession who are famous in the city. The entirety of a tekyeh complex is called by the name of the neighborhood. 
The next section discusses the data collected from field observations based on the results of library research and the components of the sense of place.

\section{Findings}

\section{Principles of Performing the Muharram Ritual in Gorgan}

The multiple results of our fieldwork for identifying and recording the performance of this ritual as well as comparing it with the existing reports from Qajar period ${ }^{2}$ (Livani, 2012, p. 55) is indicative of the multifaceted effect of the ritual on the city of Gorgan. This effect had two dimensions in Qajar period, i.e. physical and activityrelated dimensions. Although the mental dimension was also present to some extent, but it has become a stronger, mediator element only in the contemporary era. The scope of the effect of each of the above dimensions is as following:

\section{The Physical Spaces for Performing the Ritual}

The open spaces in neighborhood centers as well as the paths that connect the three main neighborhoods in the city make up the spatial-physical circulation of the ritual. Each of the three neighborhoods contains several smaller neighborhoods. Thus, the tekyeh complex of the main neighborhood is connected to the tekyeh complexes of the smaller neighborhoods. Theircommunicationaxes are based on the movement axes of Qajar period and have retained their physical pattern since then. The intra-neighborhood connections play a key role in the ritual of Muharram, with each night of the ceremonies having a different movement pattern. Table 2 classifies the main and peripheral tekyehs. There are three movement-spatial circulations in the parades of the mourning groups (figure 1). Each tekyeh lies at the center of the neighborhood and there is a holy monument next to it. The buildings of the majority of tekyehs are used as commercial units throughout the year and part of their rent payment is spent on the ritual of Muharram.

Table 2 - The classification of the neighborhoods and their main and peripheral tekyehs

(continues)

\begin{tabular}{|c|c|c|c|c|}
\hline $\begin{array}{l}\text { The main } \\
\text { neighborhoods }\end{array}$ & $\begin{array}{l}\text { The main } \\
\text { tekyehs of the } \\
\text { neighborhood }\end{array}$ & $\begin{array}{l}\text { The peripheral } \\
\text { tekyehs }\end{array}$ & $\begin{array}{l}\text { The holy building } \\
\text { near the tekyeh }\end{array}$ & $\begin{array}{l}\text { The time of the ceremony } \\
\text { of the mourning group } \\
\text { belonging to each tekyeh }\end{array}$ \\
\hline \multirow{3}{*}{$\begin{array}{l}\text { Meydan } \\
\text { neighborhood }\end{array}$} & \multirow{3}{*}{ Meydan tekyeh } & Darbeno tekyeh & Darbeno mosque & \multirow{3}{*}{ The 7th night of Muharram } \\
\hline & & $\begin{array}{l}\text { Mirkarim } \\
\text { tekyeh }\end{array}$ & Mirkarim mosque & \\
\hline & & $\begin{array}{l}\text { Doshanbe'i } \\
\text { tekyeh }\end{array}$ & $\begin{array}{l}\text { Imamzadeh } \\
\text { and Marziyeh }\end{array}$ & \\
\hline \multirow[t]{3}{*}{$\begin{array}{l}\text { Na'lbandan } \\
\text { neighborhood }\end{array}$} & \multirow[t]{2}{*}{$\begin{array}{l}\text { Na'lbandan } \\
\text { tekyeh }\end{array}$} & $\begin{array}{l}\text { Sarcheshmeh } \\
\text { tekyeh }\end{array}$ & Imamzadeh Noor & \multirow[t]{2}{*}{ The 5th night of Muharram } \\
\hline & & Pasarv tekyeh & Congregation mosque & \\
\hline & & $\begin{array}{l}\text { Mikhchehgaran } \\
\text { tekyeh }\end{array}$ & $\begin{array}{l}\text { Mikhchehgaran } \\
\text { mosque }\end{array}$ & \\
\hline
\end{tabular}

Table 2 - The classification of the neighborhoods and their main and peripheral tekyehs

(conclusion)

\section{Sarpir tekyeh Pir Seyyed Nasir tomb}

\footnotetext{
${ }^{2}$ The oldest documents which describe the way this ritual was performed in the past date back to Qajar period.
} 


\begin{tabular}{l|l|}
\hline $\begin{array}{l}\text { Dabbaghan } \\
\text { [=tanners }] \\
\text { tekyeh }\end{array}$ & Tanners' Guild \\
\hline
\end{tabular}

Source: The authors.

Figure 1 shows the spatial structure of the city in Qajar period. This map depicts the location of the tekyehs as well as their spatial connections through the movement axes. Construction of tekyehs around the walls of the central space of neighborhoods has facilitated participation in the ritual by increasing the legibility of the neighborhoods' central space and creating a unique image. The connecting paths are still used as in the past. In spite of the numerous tekyehs in each neighborhood center (which are named after the endowing families), the fact that the tekyeh complex is only named after the neighborhood without mentioning any of the endowers can be indicative of the inherent importance of the quality of performing the ritual apart from who has provided the necessary place and equipment.

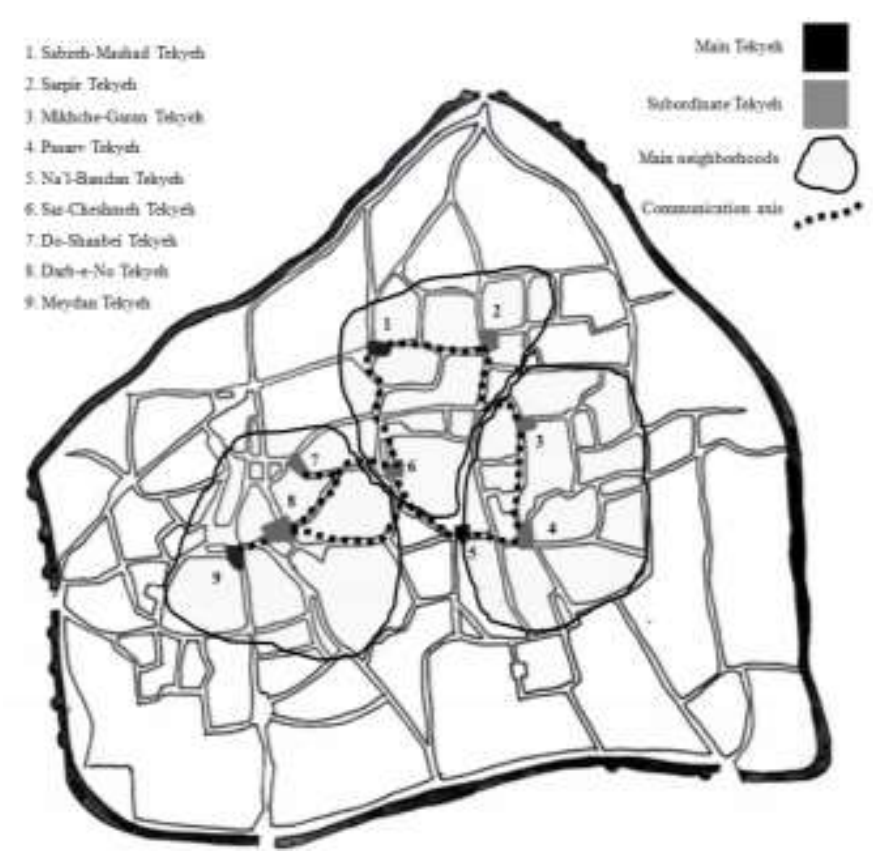

Figure 1 - Map of the city in Qajar period and the location as well as the spatial connection of the tekyehs. Source: The authors.

\section{Activities Performed in the Muharram Ritual}

The ritual of Dasteh-ravi involves several ceremonies with different patterns of time and performance. Table 3 represents the details of how this ritual is performed.

Table 3 - Comparison of Dasteh-ravi ceremony in Muharram and its implementation circulation 
Developing a conceptual model for the relationship between rituals and the city based on the Theory of Sense of Place

\begin{tabular}{|c|c|c|c|c|c|c|}
\hline Ceremony & Date & $\begin{array}{l}\text { Beginning } \\
\text { and end } \\
\text { points }\end{array}$ & Time & $\begin{array}{l}\text { The movement path } \\
\text { of mourning groups }\end{array}$ & Activities & Hosts \\
\hline \multirow[t]{2}{*}{$\begin{array}{l}\text { Dasteh- } \\
\text { ravi } \\
\text { (movement } \\
\text { of the } \\
\text { mourning } \\
\text { group) }\end{array}$} & $\begin{array}{l}\text { The } 4^{\text {th }} \\
\text { night of } \\
\text { Muharram }\end{array}$ & $\begin{array}{l}\text { Mirkarim } \\
\text { tekyeh } \\
\text { Meydan } \\
\text { tekyeh }\end{array}$ & $\begin{array}{l}\text { After } \\
\text { the } \\
\text { evening } \\
\text { prayer }\end{array}$ & $\begin{array}{l}\text { 1. Mirkarim tekyeh; } 2 . \\
\text { Doshanbe'i tekyeh; } 3 . \\
\text { Sarcheshmeh tekyeh; } \\
\text { 4. Sabzeh-mashhad } \\
\text { tekyeh; 5. Dabaghan } \\
\text { tekyeh; 6. Sarpir } \\
\text { tekyeh; } \\
\text { Mikhchehgaran } \\
\text { tekyeh; 8. Pasarv } \\
\text { tekyeh; 9. Nalbandan } \\
\text { tekyeh; 10. Meydan } \\
\text { tekyeh. }\end{array}$ & $\begin{array}{l}\text { Gathering in } \\
\text { Mirkarim } \\
\text { tekyeh; } \\
\text { movement } \\
\text { along the paths } \\
\text { and reciting } \\
\text { noheh; stopping } \\
\text { in each tekyeh; } \\
\text { people's } \\
\text { watching } \\
\text { ta'ziyeh and } \\
\text { noheh in each } \\
\text { neighborhood } \\
\text { and joining the } \\
\text { mourning } \\
\text { group to move } \\
\text { to the next } \\
\text { tekyeh. }\end{array}$ & $\begin{array}{l}\text { Mirkarim } \\
\text { tekyeh }\end{array}$ \\
\hline & $\begin{array}{l}\text { The } 5^{\text {th }} \\
\text { night of } \\
\text { Muharram }\end{array}$ & $\begin{array}{l}\text { Nalbandan } \\
\text { tekyeh } \\
\text { Meydan } \\
\text { tekyeh }\end{array}$ & $\begin{array}{l}\text { After the } \\
\text { evening } \\
\text { prayer }\end{array}$ & $\begin{array}{l}\text { 1. Nalbandan tekyeh; } \\
\text { 2. Pasarv tekyeh; } 3 . \\
\text { Mikhchehgaran } \\
\text { tekyeh; 4. Sarpir } \\
\text { tekyeh; 5. Dabaghan } \\
\text { tekyeh; 6. Sabzeh- } \\
\text { mashhad tekyeh; } 7 . \\
\text { Sarcheshmeh tekyeh; } \\
\text { 8. Doshanbe'i tekyeh; } \\
\text { 9. Mirkarim tekyeh; } \\
\text { 10. Meydan tekyeh. }\end{array}$ & $\begin{array}{l}\text { Gathering in } \\
\text { Nalbandan } \\
\text { tekyeh; } \\
\text { movement } \\
\text { along the paths } \\
\text { and reciting } \\
\text { noheh; stopping } \\
\text { in each tekyeh; } \\
\text { people's } \\
\text { watching } \\
\text { ta'ziyeh and } \\
\text { noheh in each } \\
\text { neighborhood } \\
\text { and joining the } \\
\text { mourning } \\
\text { group to move } \\
\text { to the next } \\
\text { tekyeh. }\end{array}$ & $\begin{array}{l}\text { Nalbandan, } \\
\text { Pasarv, and } \\
\text { Mikhchehgaran } \\
\text { tekyehs }\end{array}$ \\
\hline
\end{tabular}

Table 3 - Comparison of Dasteh-ravi ceremony in Muharram and its implementation circulation

(conclusion) 


$\begin{array}{lrll}\text { The } 6^{\text {th }} & \text { Sarcheshmeh } & \text { After } \\ \text { night of } & \text { tekyeh }- & \text { the } \\ \text { Muharram } & \begin{array}{l}\text { Meydan } \\ \text { tekyeh }\end{array} & \begin{array}{l}\text { evening } \\ \text { prayer }\end{array}\end{array}$

1. Sarcheshmeh tekyeh; 2. Sabzehmashhad tekyeh; 3.

Dabaghan tekyeh; 4. Sarpir tekyeh; 5 Mikhchehgaran tekyeh; 6. Pasarv tekyeh; 7

Nalbandan tekyeh;

8. Darbeno tekyeh; 9. Meydan tekyeh.
Gathering in SabzehSarcheshmeh tekyeh; movement along the paths and reciting

noheh; stopping in each tekyeh; people's watching ta'ziyeh and noheh in each neighborhood and joining the mourning group to move to the next tekyeh.

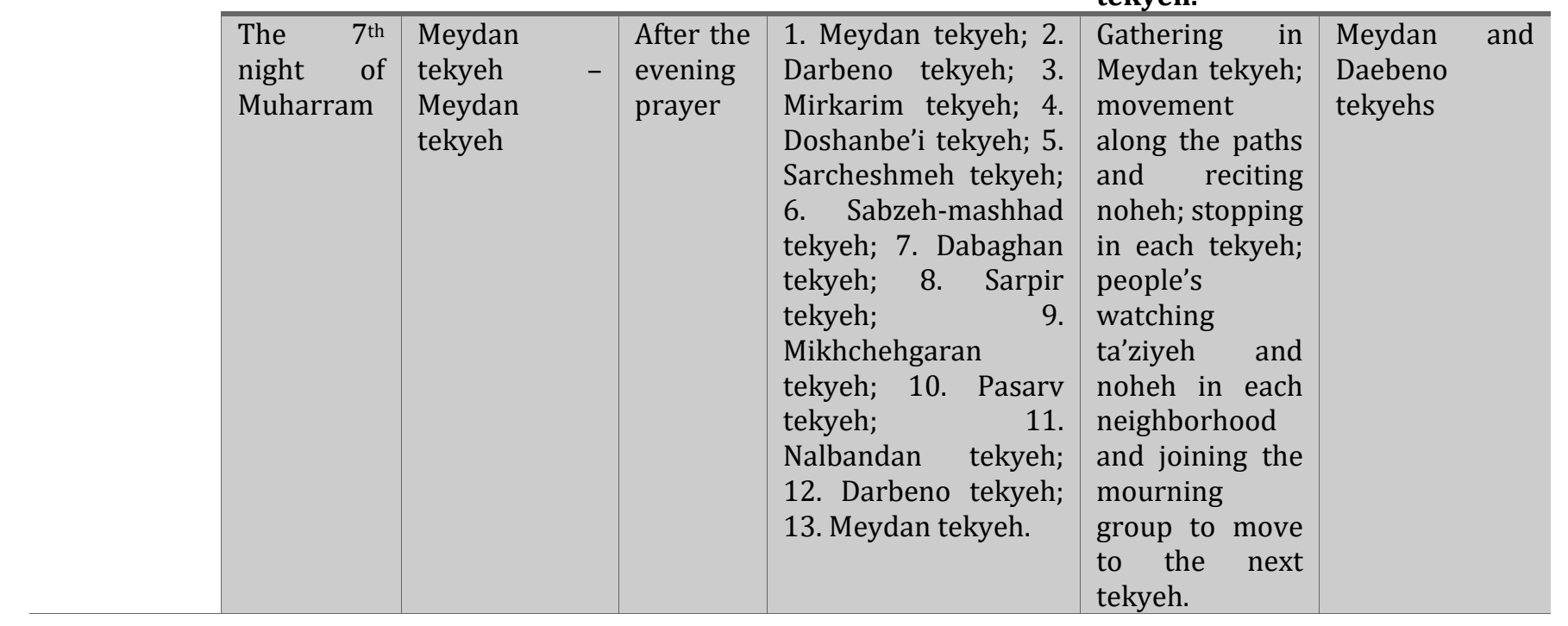

mashhad, Sarcheshmeh, and Sarpir tekyehs

Source: The authors.

Other ceremonies of the Muharram ritual (Table 4) include Togh-bandan, Pa-menbari, Sham-e Ghariban, and Dasteh-choobi. These ceremonies are only held once at one night. The spatial-physical circulation of these ceremonies isslightly different from that of the main ritual which covers more peripheral alleys. The destination of movement in the peripheral alleys is houses in which mourning equipment (such as flags) are kept or the symbolic menbar(i.e. a high chair for a preacher) is placed and candles are lighted as part of the Pa-menbari ceremony. Following these ceremonies, the spatial-physical circulation of the ritual extends further into the smaller branched routes, making them more crowded and increasing their security. Table 4 shows the details of how these ceremonies are performed.

Table 4 - Comparison of the ceremonies of Togh-bandan, Pa-menbari, Dasteh-choobi, and Sham-e Ghariban during Muharram and their circulation

$\begin{array}{lllll}\text { Ceremony } & \text { Date } & \text { Place } & \text { Time } & \text { Activities }\end{array}$




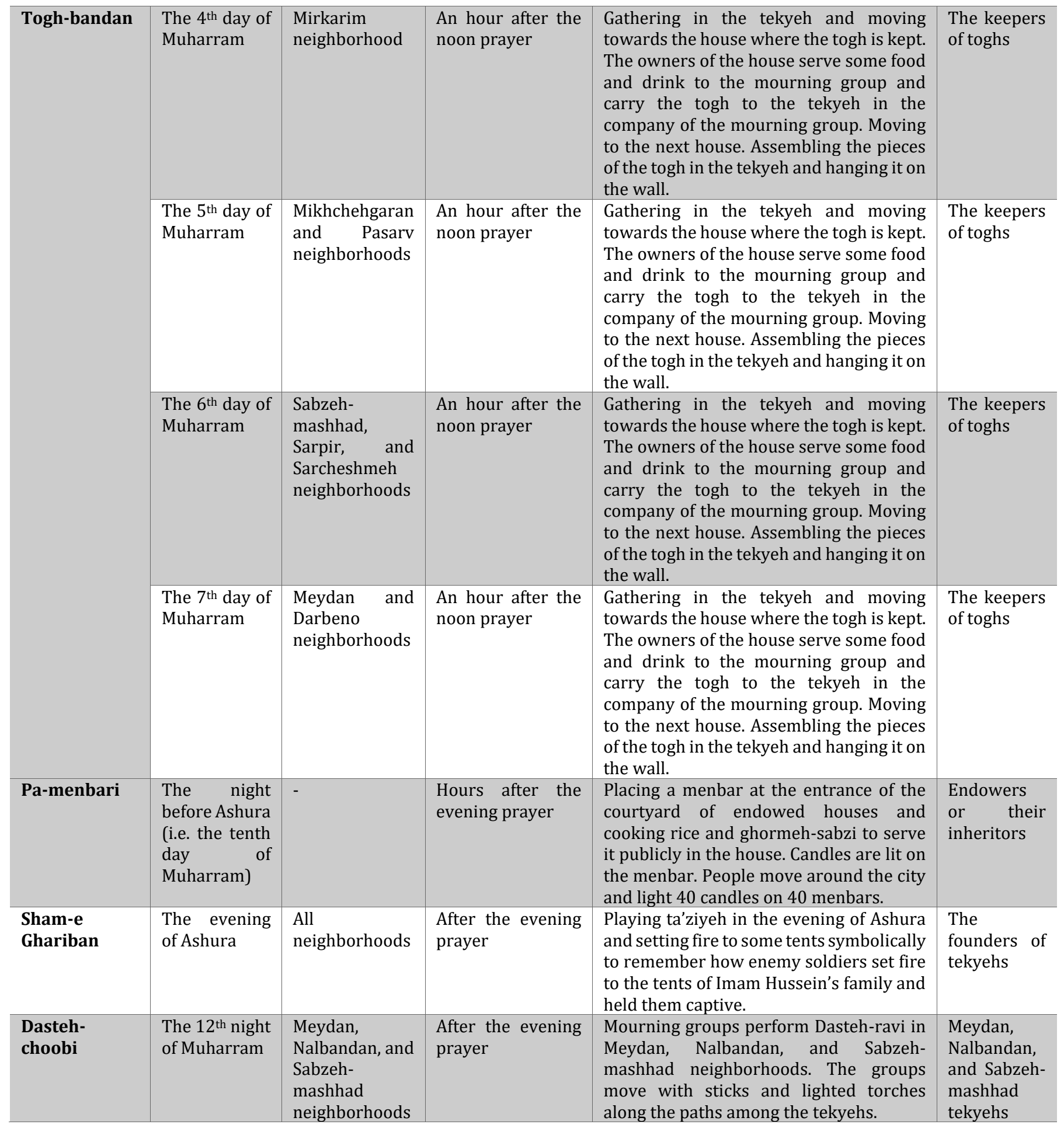

Source: The authors.

The complex of buildings within each tekyeh that belong to different founders or endowers have always encouraged their families and friends to gather in the tekyeh during the ritual of Muharram. This will increase participation in the ritual and help to maintain its physical and activity life. The variety in the movement from the source to the destination point has led to an emphasis on the entire spatial circulation of the ritual. figure 2 shows the neighborhood centers and the spatial circulation of ceremonies in these centers in the general spatial structure of the city. 


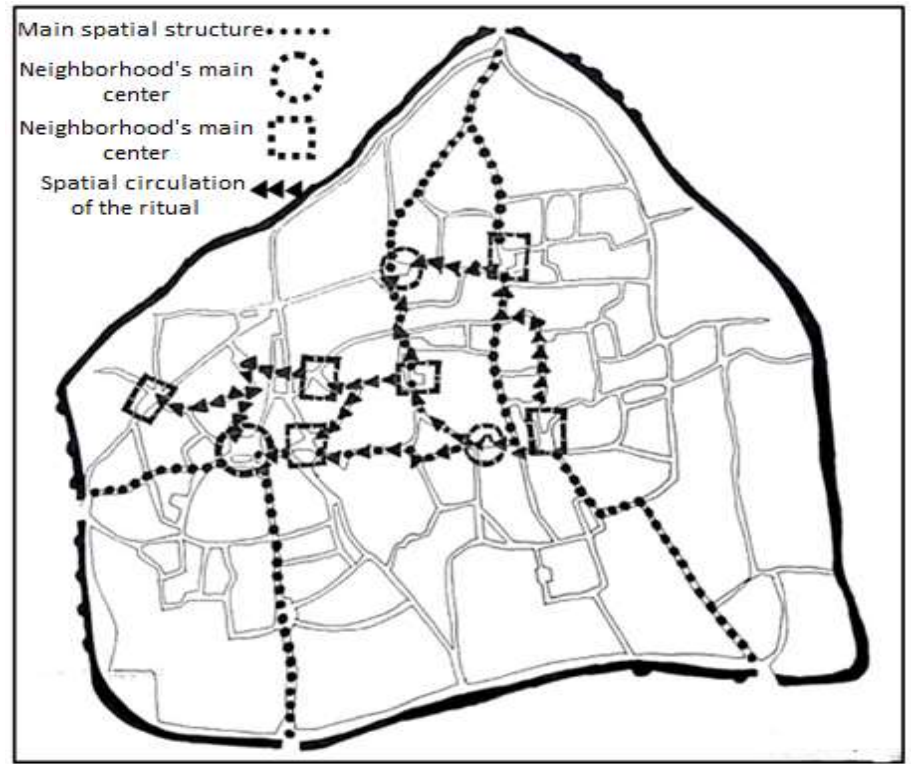

Figure 2 - The spatial circulation of the Muharram ritual and the main movement axes of the city in Qajar period. Source: The authors.

Our data of the performance activities and the physical spaces used for stopping and movement display highly significant relationships. Formation of the tekyehs as a physical place for the collective ritual of Muharram in neighborhood centers and the fact that the neighborhood centers were named after the tekyeh clearly indicates the effect of tekyehs on neighborhoods(Afshar, 1995; Livani, 2012, p. 44). Moreover, in addition to the initial changes in the upper floors of the walls around the neighborhood centers, the tekyehs gradually resulted in a number of interesting physical changes in neighborhood centers:

- The tekyehs had originally platforms in ground floor and porches in upper floors for women to stand and gather for the ceremonies.

- In the course of time and with the advancement of technology, as the time of Muharram shifted toward cold seasons, the open porches in upper floors were covered with walls that contained transparent openings. As a result, the appearance of the exterior walls of neighborhood centers was changed (Table 5).

Table 5 - Comparing the porches and windows in the first floors of tekyehs 


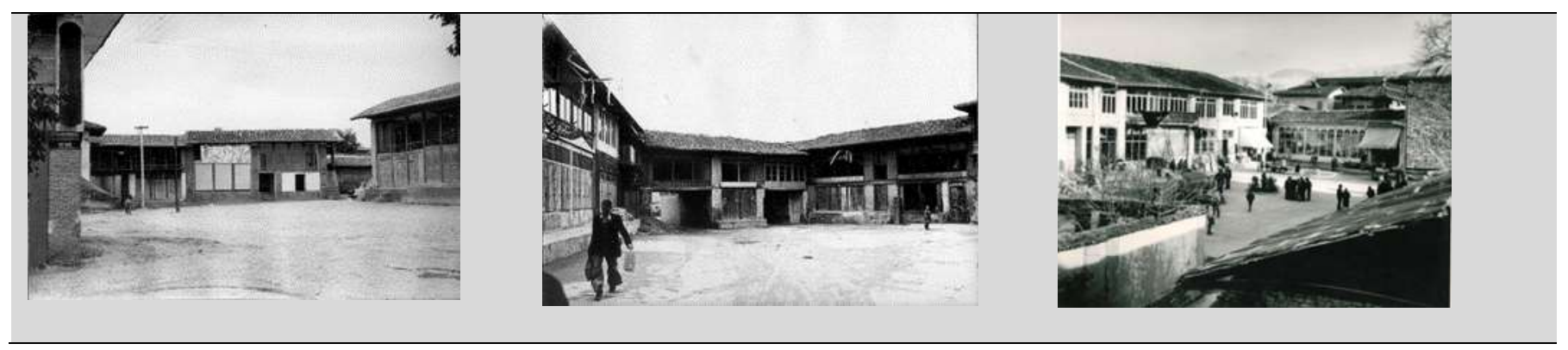

Source: Gorgan Cultural Heritage Organization(year of the phtos: left:1972, Sabze-Mashad 1973, midlle: Darb-e-No , right: Pasarv: 1977).

The above discussion clearly shows the physical effects of the Muharram ritual on the historical texture of Gorgan.

\section{Survival of the Ritual throughout Centuries and Formation of a Strong Mental Image}

The fact that this ritual has lived on throughout the centuries is of great importance. One of the main reasons is volunteer groups and local figures who help every year to hold and manage the ceremonies of Muharram. The endowments of the past have been important for the survival of the ritual from three viewpoints:

- preparing the physical context for improving the quality of the presence of the participants;

- providing financial support for the ceremonies;

- and hereditary appointment of a person to manage the ritual ceremonies.

The existing endowment documents concerning the place of mourning gatherings and parades and the support of the endower's family for financial resources have contributed to the sustenance of the physical life of tekyehs by creating responsibility among younger generations for managing the ritual. This has resulted in volunteer participation of the inheritors in holding and promoting the ceremonies. This is indicative of nongovernmental management of space during the ritual of Muharram and a prime example of the effect of the physical environment on the sustenance of this ritual. The familial presence is related to the inner space of tekyehs. Spectators from around the city attend the open space of the complex to watch the performance of the mourning group. When the group leaves the space, the spectators quit their role and join the group as participants to accompany it from one tekyeh to another. Thus, the number of participants gradually increases during the ceremony. Sustenance of the ritual over centuries has created collective memories and made meanings for the city and the Muharram ritual in the mind of the residents (Moghasemi, 2015) These mental effects are due to the variety in terms of the time of performance, place of performance, and types of activities involved in the spatial-physical circulation of the ritual. The spatial-physical circulation of the Muharram ritual is shared by the numerous people who attend public spaces and can have remarkable functional and visual effects on the mind of space users.

The documents and field observations concerning the Muharram ritual are indicative of a wide range of activities, physical spaces, and mental impressions which result from the presence of people in the ceremonies. Establishment of tekyehs in upper floors (in addition to the ground floor) to allow people to watch the ceremonies has created a unique urban image. Spatial interconnections among the tekyehs through the organic paths of the texture have created a powerful, closed circulation in the texture. The penetration of the spatialphysical circulation of the ceremonies into more peripheral paths and even into the courtyard of private houses during the Pa-menbari ceremony not only extends the spatial circulation but also enhances the sensory richness of the space. These effects run through the entire historical texture of Gorgan. By transforming the connecting 
axes among the tekyehs to pedestrian paths and changing the inside space of the tekyehs to containers for holding ceremonies, the presence of participants is maximized. The visual change of tekyehs and the spatial circulation of the ritual can be divided in two general aspects:

- the duration of the change: temporary or permanent;

- the scale of their effect on the physical dimension of the historical texture: small scale or large scale.

Table 6 provides an analysis of the building blocks of the Muharram ritual and their effect on the physical environment of the city.

Table 6 - Analysis of the Muharram ritual and its effects on the physical environment of the historical texture

(continues)

\begin{tabular}{|c|c|c|c|c|c|}
\hline \multirow{2}{*}{\multicolumn{2}{|c|}{$\begin{array}{l}\text { The building blocks of the } \\
\text { ritual }\end{array}$}} & \multicolumn{4}{|l|}{ Physical effect } \\
\hline & & \multirow[b]{2}{*}{$\begin{array}{l}\text { Permanent } \\
\text { Establishing } \\
\text { tekyehs in upper } \\
\text { floors } \\
\text { surrounding the } \\
\text { space }\end{array}$} & \multirow{2}{*}{ Temporary } & \multirow[b]{2}{*}{$\begin{array}{l}\text { Large scale } \\
\text { Effectiveness } \\
\text { on the } \\
\text { neighborhood } \\
\text { scale by } \\
\text { creating } \\
\text { tekyehs }\end{array}$} & \multirow[t]{2}{*}{ Small scale } \\
\hline $\begin{array}{l}\text { Stopping } \\
\text { space }\end{array}$ & $\begin{array}{l}\text { Spatial openness; } \\
\text { sociopetalness; } \\
\text { stopping }\end{array}$ & & & & \\
\hline $\begin{array}{l}\text { Movement } \\
\text { axis }\end{array}$ & $\begin{array}{l}\text { Guiding; } \\
\text { connecting the } \\
\text { stopping places }\end{array}$ & $\begin{array}{l}\text { Connecting } \\
\text { tekyehs and } \\
\text { creating spatial } \\
\text { circulation }\end{array}$ & $\begin{array}{l}\text { Changing the } \\
\text { axes into } \\
\text { pedestrian } \\
\text { paths }\end{array}$ & $\begin{array}{l}\text { Being effective } \\
\text { on the } \\
\text { neighborhood } \\
\text { scale through } \\
\text { creating spatial } \\
\text { circulation for } \\
\text { the ritual }\end{array}$ & - \\
\hline \multirow[t]{2}{*}{$\begin{array}{l}\text { Static } \\
\text { collective } \\
\text { activity }\end{array}$} & Ta'ziyeh & $\begin{array}{l}\text { Construction of } \\
\text { tekyehs in } \\
\text { neighborhood } \\
\text { centers for } \\
\text { ta'ziyeh }\end{array}$ & $\begin{array}{lr}\text { Changing } & \text { the } \\
\text { space } & \text { of } \\
\text { tekyehs } & \text { to } \\
\text { spaces } & \text { for } \\
\text { gathering } & \text { and } \\
\text { watching } & \\
\text { ta'ziyeh } & \end{array}$ & $\begin{array}{l}\text { Being effective } \\
\text { on the } \\
\text { neighborhood } \\
\text { scale }\end{array}$ & $\begin{array}{l}\text { Changing the visual } \\
\text { appearance of } \\
\text { tekyehs and } \\
\text { creating legibility } \\
\text { during the time of } \\
\text { ta'ziyeh }\end{array}$ \\
\hline & $\begin{array}{l}\text { Mourning } \\
\text { ceremonies in } \\
\text { mosques and } \\
\text { tekyehs }\end{array}$ & - & $\begin{array}{lr}\text { Changing } & \text { the } \\
\text { space } & \text { of } \\
\text { tekyehs } & \text { to } \\
\text { places } & \text { for } \\
\text { mourning } & \\
\text { ceremonies } & \end{array}$ & $\begin{array}{l}\text { Being effective } \\
\text { on the } \\
\text { neighborhood } \\
\text { scale }\end{array}$ & - \\
\hline $\begin{array}{l}\text { Dynamic } \\
\text { collective } \\
\text { activity }\end{array}$ & Mourning group & $\begin{array}{l}\text { Creating spatial } \\
\text { circulation for } \\
\text { holding } \\
\text { ceremonies }\end{array}$ & $\begin{array}{l}\text { Changing the } \\
\text { axes and } \\
\text { neighborhood } \\
\text { centers } \\
\text { (tekyehs to } \\
\text { pedestrian } \\
\text { areas }\end{array}$ & $\begin{array}{l}\text { Creating } \\
\text { specific spatial } \\
\text { circulations on } \\
\text { the } \\
\text { neighborhood } \\
\text { scale for } \\
\text { holding } \\
\text { ceremonies }\end{array}$ & $\begin{array}{l}\text { Changing the visual } \\
\text { landscape and } \\
\text { creating legibility } \\
\text { during the } \\
\text { performance of the } \\
\text { mourning groups }\end{array}$ \\
\hline
\end{tabular}

Table $\mathbf{6}$ - Analysis of the Muharram ritual and its effects on the physical environment of the historical texture 


\begin{tabular}{|c|c|c|c|c|c|}
\hline & Togh-bandan & - & $\begin{array}{l}\text { Carrying the } \\
\text { toghs to } \\
\text { tekyehs and } \\
\text { installing } \\
\text { them on the } \\
\text { top of the walls }\end{array}$ & - & $\begin{array}{l}\text { Changing the } \\
\text { visual } \\
\text { appearance of } \\
\text { tekyehs and } \\
\text { creating legibility } \\
\text { in the space }\end{array}$ \\
\hline & Dasteh-choobi & $\begin{array}{l}\text { Creating spatial } \\
\text { circulation for } \\
\text { holding } \\
\text { ceremonies }\end{array}$ & $\begin{array}{l}\text { Changing the } \\
\text { axes and } \\
\text { neighborhood } \\
\begin{array}{l}\text { centers } \\
\text { (tekyehs to } \\
\text { pedestrian } \\
\text { areas }\end{array}\end{array}$ & $\begin{array}{l}\text { Creating a } \\
\text { specific spatial } \\
\text { circulation on } \\
\text { the } \\
\text { neighborhood } \\
\text { scale for } \\
\text { holding } \\
\text { ceremonies }\end{array}$ & $\begin{array}{l}\text { Changing the visual } \\
\text { landscape and } \\
\text { creating legibility } \\
\text { in the spatial } \\
\text { circulation during } \\
\text { the performance of } \\
\text { Dasteh-choobi }\end{array}$ \\
\hline & Pa-menbari & $\begin{array}{l}\text { Extending the } \\
\text { spatial } \\
\text { circulation and } \\
\text { bringing it to the } \\
\text { private } \\
\text { courtyards }\end{array}$ & 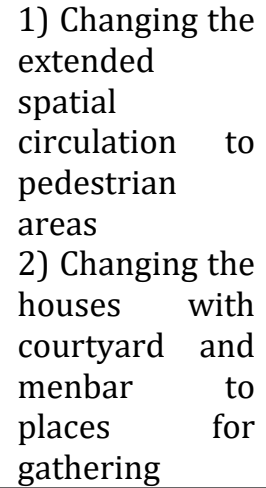 & $\begin{array}{l}\text { Extending the } \\
\text { spatial } \\
\text { circulation of } \\
\text { the ritual and } \\
\text { significant } \\
\text { increase in the } \\
\text { number of } \\
\text { stopping and } \\
\text { gathering } \\
\text { places }\end{array}$ & $\begin{array}{l}\text { Changing the visual } \\
\text { landscape of the } \\
\text { spatial circulation } \\
\text { and creating } \\
\text { legibility through } \\
\text { menbars and pots } \\
\text { of votive food }\end{array}$ \\
\hline & Sham-e Ghariban & $\begin{array}{l}\text { Creating spatial } \\
\text { circulation for } \\
\text { holding } \\
\text { ceremonies }\end{array}$ & $\begin{array}{l}\text { Changing the } \\
\text { axes and } \\
\text { neighborhood } \\
\begin{array}{l}\text { centers } \\
\text { (tekyehs to } \\
\text { pedestrian } \\
\text { areas }\end{array}\end{array}$ & $\begin{array}{l}\text { Creating a } \\
\text { specific spatial } \\
\text { circulation on } \\
\text { the } \\
\text { neighborhood } \\
\text { scale for } \\
\text { holding } \\
\text { ceremonies }\end{array}$ & $\begin{array}{l}\text { Changing the visual } \\
\text { landscape and } \\
\text { creating legibility } \\
\text { in the spatial } \\
\text { circulation during } \\
\text { the performance of } \\
\text { Sham-e Ghariban }\end{array}$ \\
\hline The hosts & $\begin{array}{l}\text { The families } \\
\text { living in the } \\
\text { neighborhood }\end{array}$ & $\begin{array}{l}\text { Creating } \\
\text { different kinds of } \\
\text { tekyeh on the } \\
\text { upper floors of } \\
\text { stopping spaces }\end{array}$ & $\begin{array}{l}\text { Decorating the } \\
\text { exterior and } \\
\text { interior walls of } \\
\text { tekyehs with } \\
\text { black materials }\end{array}$ & $\begin{array}{l}\text { Being effective } \\
\text { by building } \\
\text { tekyehs in } \\
\text { neighborhoods }\end{array}$ & $\begin{array}{l}\text { Being effective by } \\
\text { changing the visual } \\
\text { landscape creating } \\
\text { legibility in the } \\
\text { space of tekyehs }\end{array}$ \\
\hline
\end{tabular}

Source: The authors.

The effects of the Muharram ritual on the physical environment of the city change the urban landscape and create evident signs of urban life, whether sustainable (through the architecture of tekyehs) or temporary (by changing the urban landscape) ones. When combined with collective presence of people, this can create collective memories and a collective sense of belonging to space. (Rezvani, 2018)studies the historical texture of the city by measuring the sense of belonging to place through field observations and questionnaire-based interviews. In his study, the importance of the mental and activity-related dimensions in people's sense of belonging is clearly (Asad, 1993) in addition to the physical aspect. Therefore, although there is a wide variety in the physical contexts and activities of the Muharram ritual, the long history of holding this ritual has resulted in significant relationships between people and the space in which it is held. What was said above can be classified in a reductionist manner as the main elements of the Muharram ritual: 
1. The type of space for holding the ritual: This physical space acts as a spatial circulation and consists of two types:

- The stopping space of the ritual which refers to a complex of tekyehs in the center of the neighborhood for performing ta'ziyeh and the space around the mosques for holding mourning ceremonies.

- The movement space of the ritual which refers to the movement axes that interconnect the spaces of tekyehs and has remained unchanged for several centuries.

2. The activity to be performed: The activities in a ritual are either static or dynamic:

- Dynamic collective activity refers to the entire movement activities in the evenings of Muharram which begin in one tekyeh and end in another one.

- Static activity refers to activities that take place in a physical space which can contain a large number of people.

3. Making meaning for the relationship among the host, the participants, and the spatial-physical circulation of the ritual:

- Creating a collective sense of belonging to the ritual and its performance place through voluntary participation of organizers and spectators as well as changes in the physical environment to make it more suitable for the ritual. Belonging to space has encouraged people to build tekyehs in the central open spaces of neighborhoods and clearly specified the activity pattern in these spaces. Thus, the central tekyehs have been built due to a religious sense of belonging and are maintained based on an agreement-based sense of belonging. This has allowed for a collective sense of belonging to space. The participants can form social bonds by regularly attending the ceremonies during the time of the ritual.

As the main components of the ritual of Muharram, spatial circulation, activities, and collective memories exert a synergic effect on the city. These components may correspond to the three components of the sense of place and can also act as their subsets. Thus, the ritual and the city are linked through their components. Although the components of the ritual are subsets of the components of the sense of place in a city, they can affect a large part of the city. Figure 3 clearly shows the role of physical dimension, function, and meaning in the relationship between the ritual and the city. (figure 3)

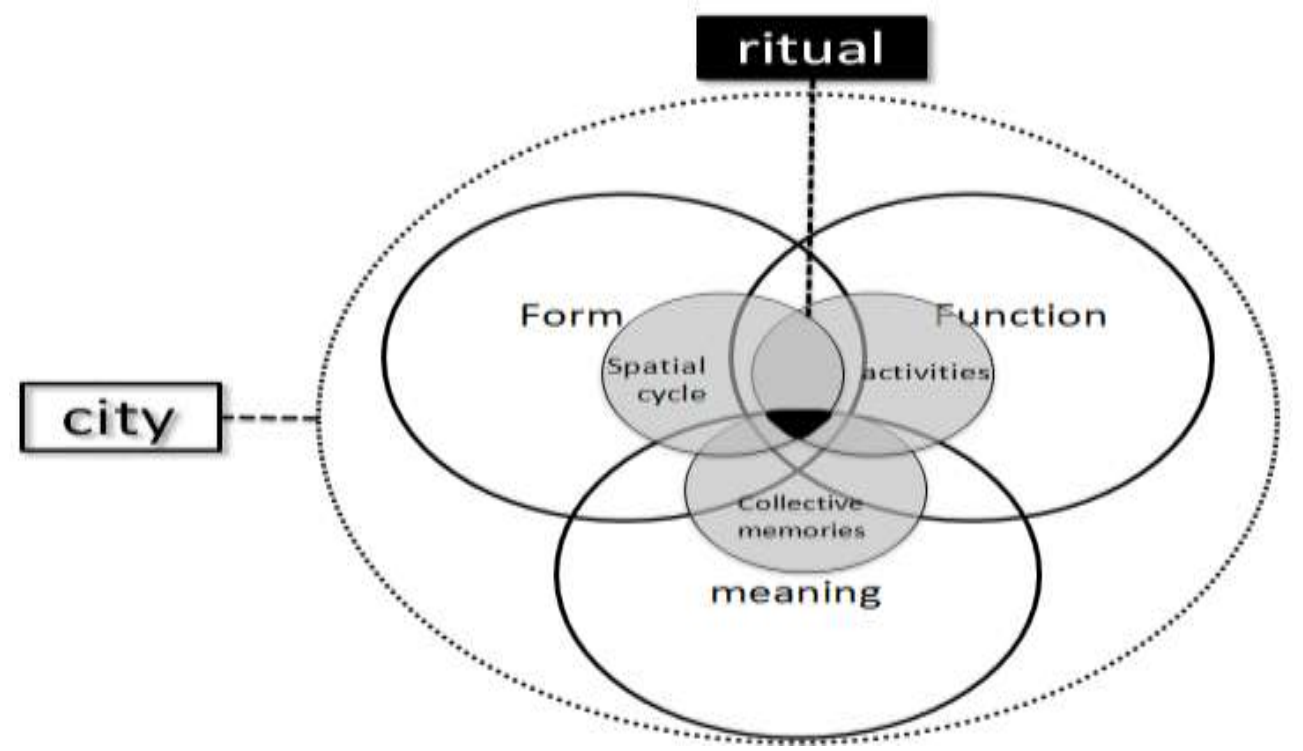

Figure 3 - The relationship between the Muharram ritual and the three components of the sense of place in the city. Source: The authors. 
Developing a conceptual model for the relationship between rituals and the city based on the Theory of Sense of Place

In general, the components of this ritual can be reduced to three broad categories, i.e. physical structure, activity structure, and mental structure. These structures are mutually interrelated. Reinforcement of each of them will reinforce the other structures. The Muharram ritual influences the layers of the city through this three-fold structure. The next section will discuss this influence in detail.

\section{Discussion}

When modified in the month of Muharram, the physical and functional dimensions of the city create meanings that will be remembered by the citizens and bring about a sense of belonging. The physical structure can be easily recognized due to the often permanent nature of changes. The activity structure enjoys increased legibility due to temporary changes as a result of the spatial circulation of the Muharram ritual. The mental structure, however, is only possible to achieve through direct presence in the space and discovering the lived experience of people as well as hearing their related experiences. It can be stated that, through its physical and activity structures, the ritual of Muharram has had a tangible effect on the city, which is partly permanent and partly temporary. In the mental structure, however, this effect penetrates the hidden meaning layers of the city and finds intangible manifestations. The mental structure will be stable as long as the physical and activity structures are maintained and revived. Despite being intangible, this structure is the underlying layer of the physical and functional dimensions of the city and plays a crucial role in the transformation of urban spaces to places as well as in the creation of the sense of belonging. The ritual of Muharram has received remarkable public participation in almost all historical periods. In each period, due to the voluntary participation of people and changing the appearance of the city to a special mode, it has created many individual and collective memories. Changing the central spaces of neighborhoods to places for performing the ritual is indicative of the strong sense of belonging among the participants. Thus, the sustenance of this ritual over centuries has made it a legacy to be transferred from one generation to the next. This legacy no longer belongs to a certain group of people and is now part of the urban identity and meaning. The physical, activity, and mental structures of this ritual have certain effects on the city and together result in enduring transformations in the physical environment, landscape, and meaning of the city.

The ritual of Muharram is a collective ritual which originally consisted of fluid movements in open urban spaces. In the course of its evolution, this ritual has created new spaces and modified the existing spaces, thus finding its own spatial-physical circulation. The sustenance of this ritual over the last two centuries has resulted in spaces with certain sensory richness and a specific sense of place. Importantly, the sense of place has its roots in the activity, instead of the physical, dimension. In the beginning, the activities performed in the Muharram ritual were influenced by religious Shi'ite beliefs and did not depend on specific places. The aim was to merely commemorate the Day of Ashura and the martyrdom of Imam Hussein. Using neighborhood centers for the gathering of people and paths for connecting the centers facilitated the joining of the inhabitants of different neighborhoods. Formation of specific places and construction of tekyehs, which resulted in sustainable physical changes in urban spaces, occurred in Qajar period after several centuries of holding the ritual. According to the theory of the sense of place, however, the existence of physical space is the prerequisite to any collective memory and a sense of place. The suggestion made so far by various researchers include focus on physical and visual features, access to urban spaces to encourage individuals to attend the spaces and perform collective activities, and creating collective memories. Thus, these activities occur in the context of place. The ritual ceremonies of Muharram, however, did not have a specific physical structure well after a century of their beginning in Iranian cities and the construction of tekyehs and Husseinyehs began only in Qajar period. To sum up, it can be argued that, as a non-urban factor, the Muharram ritual has influenced the activity, physical, and mental structure of urban spaces and created a sense of place in its unique spatial-physical structure(figure 4). 


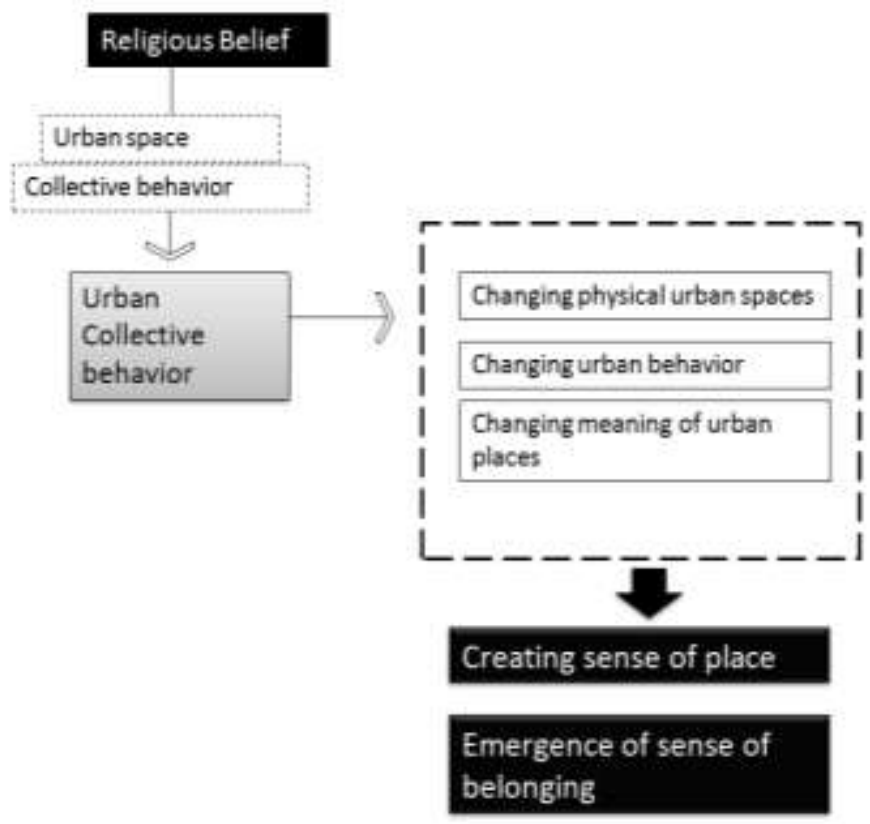

Figure 4 - The process of creating sense of place through the religious belief. Source: The authors.

\section{Conclusion}

The aim of this paper was to investigate the influence of the Muharram ritual on city and citizens as well as the different layers of this influence. To this end, the effect of this ritual on the physical, functional, and meaning-related dimensions of the city was studied. The data were collected using an exploratory approach through fieldwork and examination of historical documents. The Muharram ritual was developed as a religiously-motivated, collective behavior in the beginning centuries of the Islamic era among Iranian Shi'ites. Although it was initially shaped by nonurban-development factors, its popularity and significance gradually led to physical changes in urban structures and neighborhood centers. The effect of this ritual is also visible in urban functions. During the time of this ritual, the normal state of the city is suspended and the routine activities undergo a liminal transformation. Sustenance of these changes over centuries and annual participation of volunteers to make the changes gives a specific meaning to the city during this time which influences any user in addition to the organizers and participants. The relationship between the physical environment and observers as well as participation in this collective ritual has accumulated memories and created a specific mental image in the mind of people. Changing the physical environment by the users, which is a kind of signature, and the flow of the ceremonies of the ritual into this environment are major factors of the sense of place which help to internalize people's understanding of space. Thus, a mental image can be created and the environment can turn into a structure through which people develop a sense of belonging to the liminal conception of space. The main point of this discussion is how the sense of place is generated. As non-urbandevelopment phenomenon, the Muharram ritual has produced its specific places to which people have developed a sense of belonging over centuries. In this context, people's mental images and memories are the main tools of creating identity for these places. This refers to the mental dimension of the ritual which strongly depends on physical and activity-related dimensions. The physical structure of this ritual which has created a secondary spatial structure in the Qajar city can be viewed as an enduring change. In this regard, the physical structure of the ritual is a tangible structure that can be observed throughout the year by attending the neighborhoods in the historical texture and the paths which connect them. The activity-related structure of the ritual is temporary and is only visible during the ritual of Muharram. The condition for the sustenance of the mental structure of the ritual and the transfer 
of this structure to future generations is continue this ritual and maintain its physical structure. Otherwise, this structure would lose its ability to be transferred to the next generation.

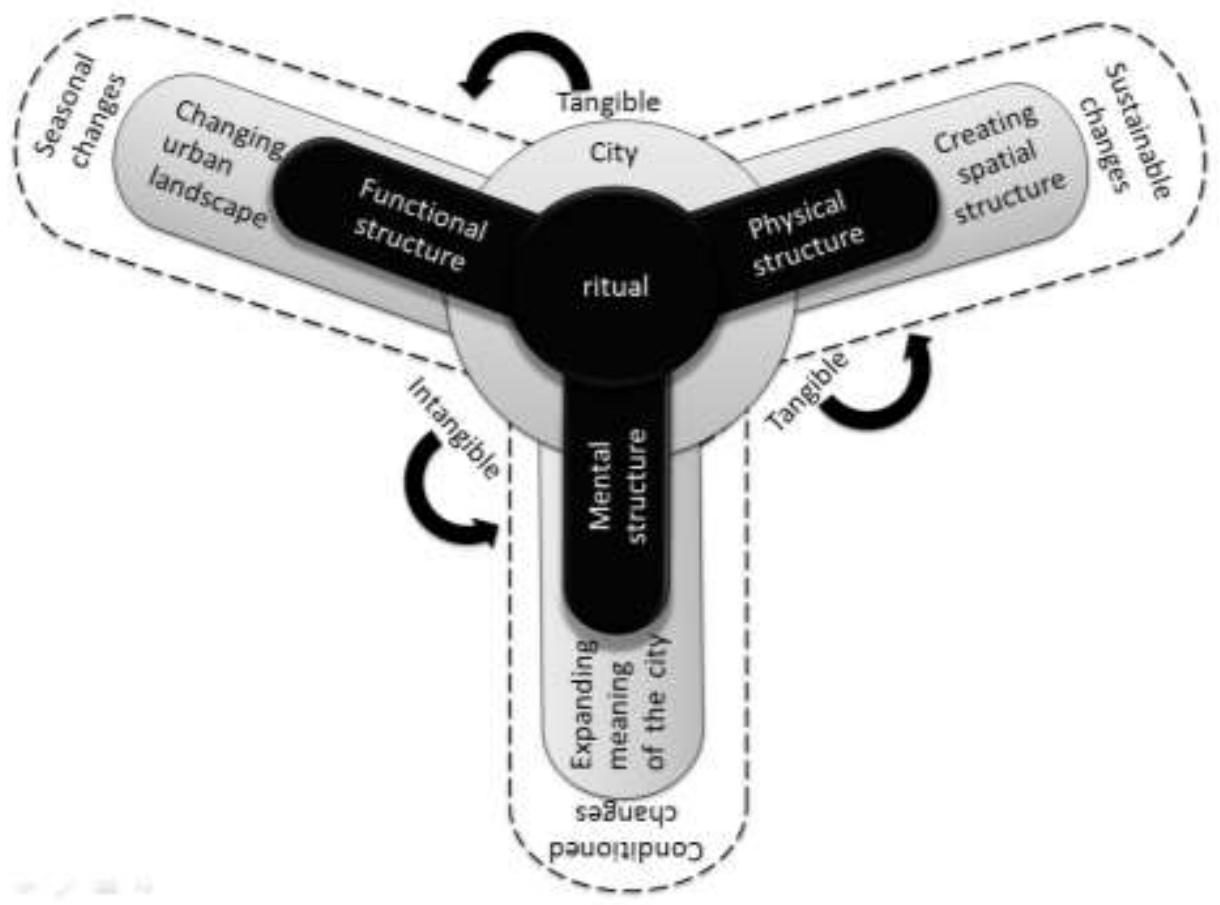

Figure 5 - The conceptual model of the relationship among the components of rituals and the place structure of the city. Source: Authors.

\section{References}

Afshar, I. (1995). Tarikh-E Chehel-Sale-ye Iranian: Dore-ye Padeshahi-ye Naser-Addin-Shah[Forty Years of Iranian History: the Reign of Nasser al-Din Shah]. Tehran: Asatir.

Ahari, Z. (2015). Shenasayi-ye Sakhtar-e Sanaviye-ye Shahr-e Irani dar Dore-ye Ghajariye[Identification of the Secondary Structure of the Iranian City in Qajar Era.] Fine Arts[in persian], vol(20), 23-34.

Avery, P., Hambly, G., \& Melville, C. (1991). Iranian History of Pahlavi Era: From Reza Shah to the Islamic Revolution. Cambridge: Cambridge University press.

Asad, T. (1993). Genealogies of Religion: Discipline and Reasons of Power in Christianity. Baltimore, MD: Johns Hopkins University Press.

Bentley, I. E. (1985). Responsive Environments: A Manual for Design. London: The Architectural.

Bineshifar, F. (2015). Seir-e Tahavol-e Roze va Rozeh-khani dar Dorane Gajar[The Evolution of Rawzah in the Qajar Period]. Kharazmi History-letter[in persian], vol(10),47-72.

Canter, D. (1977). The Psychology of Place. London: Architectural Press.

Chelkowski, P. (1979). Ta'ziyeh: Ritual and Drama in Iran. New York: NYU Press.

Falahat, M. S. (2006). Model-e Mafhoomi-e Hess-e Makan va Avamele Sazande-ye Aan [The Concept of Sense of Place and the Factors Shaping it]. Journal of Fine Arts[in persian],vol(26), 57-66.

Gluckman, M. (1962). 'Les Rites de Passage'. In M. Gluckman, Essays on the Ritual of Social Relations (pp. 1-52). Manchester: Manchester University Press. 
Habibi, R. (2008). Tasvir-e Zehni va Modele Mafhoomi-e Makan[Mental image and the concept of place]. Journal of Fine Arts[in Persian], vol(35), 39-50.

Hesam Mazaheri, M. (2008). Jame-e Shenasi-ye Aeen-haye Soogvari va Hei'at-haye Mazhabi dar Iran[Sociology of Mourning Rituals and Religious Delegations in Iran (Shiite media)]. Tehran: International Publishing.

Howkes, J. (2001). The fourth pillar of sustainability: culture's essential role in public planning. New York: Common Ground Publishing.

Khaledian, S. (2014). Tabyin-e Jaygah-e Eslam dar Ravand-e Shahr-neshini va Sazman-e Faza-ye shahri-ye Iran[Explaining Islam's Position in Urbanization and Urban Spatial Organization of Iran.] Journal of Studies on Iranian Islamic City[in Persian], $\operatorname{vol}(17), 5-18$.

Livani, M. (2012). Barresi-ye Nagsh-e Marasem-e Ayini dar Baz-Afarini-ye Sakhtar-e Baft-e Tarikhi-ye Gorgan[Investigating the Role of Rituals in Reconstructing Gorgan Historic Texture](unpublished MA thesis).Tehran, Tehran, Iran.

Lotfi, S. (2008).Hefazat va Baz-Afarini-ye Shahri, Mafahim va Sharayet [Urban Conservation and Recreation, Concepts and Conditions (From the 1990s onwards)](unpublished Phd thesis).Tehran, Tehran, Iran.

Lynch, K. (1979). The Image of The City. Massachusetts: Massachusetts Institute of Technology.

Masoudinejad, R. (2018). The Rite of Urban Passage, The Spatial Ritualization of Iranian Urban Transformation. New York: Berghahn Books.

Masoudinejad, R. (2013). The Discursive Manifestation of Past and Present Through the Spatial Organization of the Ashura Procession. Space \& Culture, vol(16),133-160.

Mirgholami, M., \& Ayshem, M. (2016).Model-e Mafhoomi-e Arzyabi-e Hes-e Makan, bar Asas-e Moallefe-haye Kalbadi, Edraki, Amalkardi va Ejtemai, Motaleye Moredi: Khiaban-e Oroomieh [Conceptual Model of Evaluating the Sense of Place Based on Physical, Perceptual, Functional and Social Components:The Case of Imam St., Urmia, Iran]. Urban Studies [in Persian], vol(19),6980.

Moghasemi, G. (2015).Takaya-ye Gorgan, Hedayatgar-e Zendegi-e Shahri v Mahalle-i [Gorgan's Takaya: Guide to Urban and Neighborhood Life](unpublished MA thesis).University of Isfahan, Iran.

Punter, J. V. (1991). Participation in the Design of Urban Space. Landscape Design, vol(200),24-27.

Relf, E. (1976). Place \& Placeness. London: Pion.

Rezvani, N. (2018).Arzyabi-e Baft-haye Tarikhi, bar Asas-e Hanjar-e Hes-e Makan: Motale-ye Moredi-ye Mahale-ye Sarcheshmeye Gorgan [Evaluation of Historical Textures based on the Norm of Sense of Place: The Case of Sarcheshmeh Neighborhood of Gorgan]. Journal of Urban Research and planning, [in persian], vol(29),23-42.

Sotoodeh, M. (1998). From Astara to Starbad. Tehran: National Works Association, Association of Cultural Works and Honors, Ministry of Culture and Islamic Guidance. General Directorate of Publications and Advertising.

Tavakoli Bina, M. (2015). Hekmat-e Honar-e Shi'e dar Maghoole-haye Emamat, Pooyayi-e alayem, va Neshane-haye Azadari v Ziarat va Phalsapheh va Kalam [Wisdom of Shiite art in Imamate categories: Dynamics of signs and symbols of mourning and pilgrimage, philosophy and theology]. Imamate Research[in Persian], vol(17),159-186.

van Gennep, A. (1960). The Rite of Passage. London: Routledge \& K. Paul.

Zabihi, M. (1984). Gorgan-Nameh [The Book of Gorgan]. Tehran: Babak.

Editor: Rodrigo Firmino

Received:May 02, 2020

Approved: Oct. 23, 2020 